\title{
HUBUNGAN TINGKAT KECEMASAN TERHADAP TERKENDALINYA GULA DARAH PADA PASIEN DIABETES MELITUS DI PUSKESMAS PAKIS SURABAYA
}

\author{
Erika Untari Dewi \\ untarierika@yahoo.co.id
}

\begin{abstract}
ABSTRAK
Pendahuluan: Keberhasilan pengobatan pada pasien Diabetes Mellitus salah satunya dilihat dari terkendalinya kadar gula darah. Terkendalinya kadar gula darah ini dipengaruhi oleh faktor diit, aktivitas fisik, kepatuhan minum obat dan pengetahuan. Keterlibatan faktor-faktor ini dapat mempengaruhi kondisi kesehatan. Pasien Diabetes Mellitus sering datang ke Puskesmas dan dilakukan pemeriksaan gula darah banyak yang gula darahnya naik atau tidak terkendali. Penderita DM yang memiliki gangguan psikologis terutama kece- masan dan depresi meningkatkan kurangnya manajeman dan hasil terapi. Penelitian ini bertujuan untuk mencari hubungan antara tingkat kecemasan dengan kadar gula darah pada penderita DM yang dirawat di Puskesmas Pakis Surabaya Metode: Desain yang digunakan pada penelitian ini korelasi. Dalam penelitian ini menggunakan variabel independen dan dependen. Populasi dari Penelitian ini adalah seluruh pasien Diabetes Mellitus di Puskesmas Pakis. Sampel yang digunakan 40 orang dengan menggunakan teknik consecutive sampling. Pengambilan data dengan kuisioner. Data diperoleh dari hasil kuisoner, data yang terkumpul ditabulasi dengan tabel dan dikonfirmasikan dalam bentuk tabel. Hasil: Dari hasil penelitian ini didapatkan hasil adanya hubungan antara kecemasan dengan terkendalinya kadar gula darah.
\end{abstract}

Kata Kunci : terkendalinya kadar gula darah, pasien diabetes mellitus.

\section{ABSTRACT}

Introduction: The success of treatment in patients with Diabetes Mellitus one of them seen from terkendalinya blood sugar levels. Controlled blood sugar levels are influenced by diit factors, physical activity, adherence to medication and knowledge. The involvement of these factors can affect health conditions. Diabetes Mellitus patients often come to the Puskesmas and do blood sugar checks many of whose blood sugar is rising or uncontrollable. Diabetics who have psychological disorders especially anxiety and depression increase the lack of management and outcomes of therapy. This study aims to find the relationship between the level of anxiety with blood sugar levels in DM patients treated at Puskesmas Pakis Surabaya. Methode: Design used in this study correlation. In this study using independent and dependent variables. The population of this study were all Diabetes Mellitus patients at Pakis Health Center. The sample used 40 people using consecutive sampling technique. Data collection with questionnaire. Data obtained from the results of kuisoner, collected data tabulated with tables and confirmed in tabular form. Result: From the results of this study found the relationship between anxiety with controlled blood sugar levels.

Keywords: controlled blood sugar levels, patients with diabetes mellitus 


\section{PENDAHULUAN}

Saat ini di Indonesia mengalami percepatan peningkatan penderita Diabetes Mellitus, hal ini terutama diakibatkan oleh perkembangan pola makan yang salah. Menurut WHO, ( 1994 ) berbagai masyarakat telah membuktikan bahwa peningkatan masukan makanan berlemak jenuh serta penurunan makanan berserat dapat berakibat menurunnya kesensitifan insulin dan ketidaknormalan toleransi glukosa. Diabetes mellitus adalah suatu kumpulan gejala yang timbul pada seseorang yang disebabkan oleh karena adanya peningkatan kadar glukosa darah akibat kekurangan insulin baik absolut maupun relatif. ( Soegondo, 1995 ). Salah satu hal yang terpenting bagi penderita Diabetes Mellitus adalah pengendalian kadar gula darah, untuk itu pasien perlu memahami mengenai hal-hal yang mempengaruhi pengendalian kadar gula darah. Pengendalian kadar gula darah adalah menjaga kadar gula darah dalam kisaran normal seperti bukan pasien DM, sehingga dapat terhindar dari hiperglikemia atau hipoglikemia (Soegondo, 1996). Ada beberapa yang bisa mempengaruhi pengendalian meliputi faktor diit, aktifitas fisik, kepatuhan minum obat dan pengetahuan ( Soegondo, 1995 ). Penderita DM yang memiliki gangguan psikologis terutama kecemasan dan depresi meningkatkan kurangnya manajeman dan hasil terapi dibanding- kan dengan yang tidak ada gangguan psikologis (Collins \& Corcoran, 2009). Dilihat dari kenyataan dilapangan bahwa penderita Diabetes Mellitus sering datang ke Puskesmas dan dilakukan pemeriksaan gula darah banyak penderita Diabetes Mellitus yang gula darahnya naik atau tidak terkendali, ada yang kadar gula darahnya naik hingga $400 \mathrm{mg} / \mathrm{dL}$. Depresi berkaitan erat dengan hiper- gliemia dan meningkatkan resiko tim- bulnya komplikasi DM (Lustman et al, 2000), penyakit jantung koroner (De Groot et al, 2001). Pasien DM dengan depresi juga kurang suka terhadap te- rapi medis dan libih suka untuk mem- biarkan dari pada penerita DM tanpa depresi (Kinder et al, 2002; Di Matteo et al, 2000). Pada penelitian yang dilaksanakan oleh Barker et al orang dewasa Amerika didapatkan bahwa 19,5 \% terdiagnosa cemas dengan DM dan 10,9\% tanpa DM. a penelitian yang dilaksanakan oleh Barker et al orang dewasa Amirika didapatkan bahwa 19,5\% terdiagnosa cemas dengan DM dan 10,9\% tanpa DM. Menurut catatan badan kesehatan du- nia WHO sangat signifikan hubungan antara kesehtan mental dengan kese- hatan fisik. Beberapa penelitian mem- buktikan bahwa penyakit DM dicetuskan oleh adanya stres. Stres juga membuat manajemen diri sendiri lebih sulit dan berefek negatif untuk me- ngontrol kadar gula darah dan menye- babkan komplikasi (Ismail et al, 2004). Kondisi stres pada penderita DM da- pat merusak kemampuan untuk me- manfaatkan pendidikan kesehtan ten- tang penyakit DM (KDA, 2006). Kecemasan merupakan suatu respon terhadap situasi yang penuh dengan tekanan. Stres dapat didefinisikan sebagai suatu persepsi ancaman terhadap suatu harapan yang mence- tuskan cemas. Hasilnya adalah bekerja untuk melegakan tingkah laku (Rawlins, at al, 1993). Stress dapat berbentuk psikologis, sosial atau fisik. Menurut Stuart and Sundeen (1998) kecemasan ada empat tingkat, yaitu ringan, sedang, berat dan panik . Kecemasan ringan berhubungan de ngan ketegangan dalam kehidupan sehari-hari dan menyebabkan sese- orang menjadi waspada dan mening- katkan lahan persepsinya. Kecemasan sedang; Memungkinkan seseorang untuk memusatkan pada masalah yang penting dan mengesampingkan yang lain sehingga seseorang me- ngalami perhatian yang selektif, na- mun dapat melakukan sesuatu yang terarah. Kecemasan berat; Sangat mengurangi lahan persepsi seseo- rang. Seseorang dengan kecemasan berat cenderung untuk memusatkan pada sesuatu yang terinci dan spesifik, serta tidak dapat berpikir tentang hal lain. Panik berhubungan dengan ter- perangah, ketakutan dan teror karena mengalami kehilangan kendali. Orang yang sedang panik tidak mampu me- lakukan sesuatu walaupun dengan pe- ngarahan.

Respon Fisiologis terhadap Kecemasan meliputi: Kardio vaskuler; terjadi peningkatan tekanan darah, pal- pitasi, jantung berdebar, denyut nadi meningkat, tekanan nadi menurun, syok dan lain-lain. Respirasi terjadi perubahan napas cepat dan dangkal, rasa tertekan pada dada, rasa tercekik. Kulit terjadi perasaan panas atau dingin pada kulit, muka pucat, berkeringat seluruh tubuh, rasa terbakar pada muka, telapak tangan berkeringat, 
gatal-gatal. Gastro intes- tinal akan mengeluh anoreksia, rasa tidak nyaman pada perut, rasa ter- bakar di epigastrium, nausea, diare. Dan pada sistem neuromuskuler dapat menyebabkan reflek meningkat, reaksi kejutan, mata berkedip-kedip, insom- nia, tremor, kejang, wajah tegang, gerakan lambat. Insiden Diabetes Mellitus mengalami peningkatan dan di indonesia menempati urutan ke-4 menurut Badan Kesehatan Dunia ( WHO ). Prevalensi Diabetes Mellitus dari jumlah penduduk di indonesia $\pm 1,5 \%$ tiap tahun. Sehingga diperkirakan bahwa terdapat minimal 30.000 penderita Diabetes Mellitus di Surabaya, 300.000 di Jawa Timur dan 2.500.000 di seluruh Indonesia. Tahun 1994 terdapat 110,4 juta penderita Diabetes Mellitus di dunia ( Tjokroprawiro, 2003 ). Tahun 2000 di Indonesia diperkirakan terdapat 4 juta dan 175,4 juta penderita Diabetes Mellitus diseluruh dunia. Berdasarkan studi pendahuluan yang dilakukan oleh penulis di Puskesmas Pakis Surabaya didapatkan 11 dari 20 orang yang menderita penyakit Diabetes Mellitus yang datang ke Puskesmas dan dilakukan pemeriksaan gula darah didapatkan gula darahnya naik atau tidak terkendali, ada yang kadar gula darahnya naik hingga $400 \mathrm{mg} / \mathrm{dL}$. Jika kadar gula darah tidak terkontrol, komplikasi-komplikasi diabetes mellitus yang timbul misalnya pada mata, jantung, saraf dan dapat terjadi komplikasi yang akut seperti hipoglikemi dan ketoasidosis diabetikum (KAD) dimana jika tidak segera ditangani komplikasi tersebut dapat membahayakan klien. Melihat permasalahan tersebut diatas maka yang bisa dilakukan untuk memotivasi penderita diabetes mellitus dalam menjalankan pengendalian kadar gula darah dengan baik adalah mengatur diit setiap penderita sesuai dengan prinsip $3 \mathrm{~J}$ yaitu jumlah makanan, jenis dan jadwal makan. Menganjurkan penderita untuk aktifitas fisik sesudah makan. Menyarankan pasien untuk minum obat secara teratur. Memberikan suatu informasi baik melalui komunikasi, edukasi atau penyuluhan kesehatan ( KIE ) di Puskesmas atau institusi kesehatan dengan pemberian leaflet dan brosur, selain juga pendekatan yang dilakukan oleh petugas kesehatan kepada penderita diabetes mellitus sangat penting melalui kunjungan rumah. Memberikan pembelajaran kepada penderita agar mau melakukan tindakan-tindakan untuk memelihara atau mengatasi masalah-masalah dan meningkatkan kesehatannya. Guna membantu pengendalian kadar gula darah oleh karena itu peneliti tertarik dengan tujuan untuk mengetahui sejauh mana gambaran faktor-faktor yang pempengaruhi terkendalinya kadar gula darah pada pasien Diabetes Mellitus di Puskesmas Pakis Surabaya. Adanya efek yang membahayakan tersebut maka diperlukan adanya strategi pelaksanaan, dokter dan ahli gizi serta tindakan mandiri perawat seperti memantau kadar gula darah, motivasi klien untuk memantau kadar gula darah dan memberikan penyuluhan tentang pentingnya memantau kadar gula darah. Dengan diberikannya penyuluhan diharapkan klien dapat mengetahui cara pengendalian kadar gula darah dan dapat menghindari peningkatan kadar gula darah dengan demikian dapat menurunkan kadar gula darah dan juga menghindari timbulnya komplikasi untuk klien dianjurkan untuk rutin kontrol dan mengikuti olahraga diabetes dan pemberian penyuluhan keluarga agar keluarga turut mendukung program pemantauan kadar gula darah penderita.

\section{METODE}

Berdasarkan tujuan penelitian, desain penelitian yang digunakan adalah desain deskriptif korelasi dimana desain penelitian yang digunakan bertujuan untuk menghubungkan tingkat kecemasan dengan kadar gula darah pada pasien Diabetes Mellitus di Puskesmas Pakis Surabaya. Variabel independent penelitian ini adalah faktor tingkat kecemasan, Variabel dependent pada penelitian ini adalah kadar gula darah. Populasi dalam penelitian ini adalah seluruh penderita Diabetes Mellitus yang periksa ke Puskesmas Pakis Surabaya berjumlah 40 orang. Sampel pada penelitian ini adalah seluruh terkendalinya kadar gula darah pada pasien Diabetes Mellitus di Puskesmas Pakis Surabaya. Teknik sampling yang digunakan dalam penelitian ini adalah "Total Sampling" yaitu teknik penetapan sampel dengan cara memilih sampel dengan mengambil semua populasi yang ada. 
HASIL

Tabel 1. Karakteristik responden berdasarkan usia di Puskesmas Pakis Surabaya

\begin{tabular}{cccc}
\hline No. & Usia & Jumlah & Prosentase \\
\hline 1 & $\begin{array}{c}\leq 20 \\
\text { tahun }\end{array}$ & - & $0 \%$ \\
2 & $\begin{array}{c}21-40 \\
\text { tahun }\end{array}$ & - & $0 \%$ \\
3 & $\begin{array}{c}41-60 \\
\text { tahun }\end{array}$ & 30 & $75 \%$ \\
4 & $\begin{array}{c}>61 \\
\text { tahun }\end{array}$ & 10 & $25 \%$ \\
\hline & Jumlah & 40 & $100 \%$ \\
\hline
\end{tabular}

Berdasarkan tabel 1 karakteristik responden berdasarkan usia, yang paling banyak berusia 41-60 tahun yaitu 30 orang ( $75 \%$ )

Tabel 2. Karakteristik responden berdasarkan jenis kelamin di Puskesmas Pakis Surabaya

\begin{tabular}{cccc}
\hline No. & $\begin{array}{c}\text { Jenis } \\
\text { Kelamin }\end{array}$ & Jumlah & Prosentase \\
\hline 1 & Laki-laki & 8 & $20 \%$ \\
2 & Perempuan & 32 & $80 \%$ \\
\hline & Jumlah & 40 & $100 \%$ \\
\hline
\end{tabular}

Berdasarkan tabel 2 karakteristik responden berdasarkan jenis kelamin, yang paling banyak adalah Perempuan yaitu 32 orang $(80 \%)$

Tabel 3. Karakteristik responden berdasarkan Pendidikan di Puskesmas Pakis Surabaya

\begin{tabular}{cccc}
\hline No. & Pendidikan & Jumlah & Prosentase \\
\hline 1. & SD & 15 & $37,5 \%$ \\
2. & SMP & 17 & $42,5 \%$ \\
3. & SMA & 8 & $20 \%$ \\
4. & Perguruan & - & $0 \%$ \\
& Tinggi & & \\
\hline & Jumlah & 40 & $100 \%$ \\
\hline
\end{tabular}

Berdasarkan tabel 3 karakteristik responden berdasarkan pendidikan paling banyak adalah SMP 17 orang ( 42,5\% )
Tabel 4 Karakteristik responden berdasarkan pekerjaan di Puskesmas Pakis Surabaya

\begin{tabular}{|c|c|c|c|}
\hline No. & Pekerjaan & Jumlah & Prosentase \\
\hline 1. & PNS & 1 & $2,5 \%$ \\
\hline 2. & Swasta & 2 & $5 \%$ \\
\hline 3. & Wiraswasta & 6 & $15 \%$ \\
\hline 4. & IRT & 30 & $75 \%$ \\
\hline 5. & $\begin{array}{c}\text { Tidak } \\
\text { bekerja }\end{array}$ & 1 & $2,5 \%$ \\
\hline & Jumlah & 40 & $100 \%$ \\
\hline
\end{tabular}
responden berdasarkan pekerjaan yang paling banyak adalah IRT 30 orang ( $75 \%$ )

Tabel 5. Karakteristik responden berdasarkan faktor diit di Puskesmas Pakis Surabaya

\begin{tabular}{|c|c|c|c|}
\hline No. & $\begin{array}{c}\text { Faktor } \\
\text { Diit }\end{array}$ & Jumlah & Prosentase \\
\hline 1. & Patuh & 28 & $70 \%$ \\
\hline 2. & $\begin{array}{l}\text { Tidak } \\
\text { Patuh }\end{array}$ & 12 & $30 \%$ \\
\hline & Jumlah & 40 & $100 \%$ \\
\hline
\end{tabular}
bahwa faktor diit yang patuh dalam mengendalikan kadar gula darah yaitu sejumlah 28 orang ( $70 \%$ )

Tabel 6. Karakteristik responden berdasarkan faktor aktivitas fisik di Puskesmas Pakis Surabaya

\begin{tabular}{|c|c|c|c|}
\hline No. & $\begin{array}{c}\text { Faktor } \\
\text { Aktivitas } \\
\text { Fisik }\end{array}$ & Jumlah & Prosentase \\
\hline 1. & Melakukan & 33 & $82,5 \%$ \\
\hline 2. & $\begin{array}{c}\text { Tidak } \\
\text { Melakukan }\end{array}$ & 7 & $17,5 \%$ \\
\hline & Jumlah & 40 & $100 \%$ \\
\hline
\end{tabular}
bahwa faktor aktivitas fisik yang melakukan aktivitas untuk mengendalikan kadar gula darah yaitu 33 orang $(82,5 \%)$.

Tabel 7. Karakteristik responden berdasarkan faktor pengetahuan di Puskesmas Pakis Surabaya bulan Juni 2014

\begin{tabular}{cccc}
\hline No. & $\begin{array}{c}\text { Faktor } \\
\text { Pengetahuan }\end{array}$ & Jumlah & Prosentase \\
\hline 1. & Ringan & 13 & $32,5 \%$ \\
2. & Sedang & 15 & $37,5 \%$ \\
3. & Berat & 12 & $30 \%$ \\
\hline & Jumlah & 40 & $100 \%$ \\
\hline
\end{tabular}


Berdasarkan tabel 7 menunjukkan bahwa faktor pengetahuan yang berpengetahuan baik yaitu sejumlah 13 orang $(32,5 \%)$, cukup 15 orang $(37,5 \%)$ dan kurang sebanyak 12 orang ( $30 \%)$.

Tabel 8. Karakteristik responden berdasarkan terkendalinya kadar gula darah di Puskesmas Pakis Surabaya

\begin{tabular}{cccc}
\hline No. & $\begin{array}{c}\text { Terkendalinya } \\
\text { Kadar Gula } \\
\text { Darah }\end{array}$ & Jumlah & Prosentase \\
\hline 1. & Baik & 5 & $12,5 \%$ \\
2. & Sedang & 5 & $12,5 \%$ \\
3. & Buruk & 30 & $75 \%$ \\
\hline & Jumlah & 40 & $100 \%$ \\
\hline
\end{tabular}

Berdasarkan tabel 8 menunjukkan bahwa terkendalinya kadar gula darah yang baik yaitu sejumlah 5 orang ( $12,5 \%)$, sedang 5 orang ( $15 \%$ ) dan buruk sebanyak 30 orang $(75 \%)$.

Tabel 9. Tabulasi silang kecemasan dengan kadar gula

\begin{tabular}{|c|c|c|c|c|c|c|c|}
\hline \multirow{3}{*}{$\begin{array}{l}\text { Penget } \\
\text { ahuan }\end{array}$} & \multicolumn{6}{|c|}{ Kecemasan } & \multirow{3}{*}{$\begin{array}{c}\text { Tot } \\
\text { al }\end{array}$} \\
\hline & \multicolumn{2}{|c|}{ Ringan } & \multicolumn{2}{|c|}{ Sedang } & \multicolumn{2}{|c|}{ Berat } & \\
\hline & $\begin{array}{l}\mathrm{Ju} \\
\mathrm{m} \\
\mathrm{la} \\
\mathrm{h}\end{array}$ & $\begin{array}{c}\text { Pro } \\
\text { sent } \\
\text { ase }\end{array}$ & $\begin{array}{l}\mathrm{Ju} \\
\mathrm{m} \\
\mathrm{la} \\
\mathrm{h}\end{array}$ & $\begin{array}{c}\text { Pro } \\
\text { sent } \\
\text { ase }\end{array}$ & $\begin{array}{l}\text { Jum } \\
\text { lah }\end{array}$ & $\begin{array}{l}\text { Pro } \\
\text { sent } \\
\text { ase }\end{array}$ & \\
\hline Baik & 4 & $\begin{array}{l}80 \\
\%\end{array}$ & 1 & $\begin{array}{l}20 \\
\%\end{array}$ & - & - & 5 \\
\hline Sedang & 2 & $\begin{array}{l}40 \\
\%\end{array}$ & 2 & $\begin{array}{l}40 \\
\%\end{array}$ & 1 & $\begin{array}{l}20 \\
\%\end{array}$ & 5 \\
\hline Buruk & 7 & $\begin{array}{c}23,3 \\
\%\end{array}$ & 12 & $\begin{array}{l}40 \\
\% \\
\end{array}$ & 11 & $\begin{array}{c}36,7 \\
\% \\
\end{array}$ & 30 \\
\hline Jumlah & & 3 & & 5 & 12 & & 40 \\
\hline
\end{tabular}

Berdasarkan tabel 10 menunjukkan bahwa ada hubungan antara faktor kecemasan dengan terkendalinya gula darah. Hal ini ditunjukkan bahwa responden yang terkendali gula darahnya baik $80 \%$ tingkat kecemasannya ringan, terkendali gula darahnya buruk $23,3 \%$ tingkat kecemasannya ringan.

\section{PEMBAHASAN}

Berdasarkan hasil uji Kolmogorove Sminornove test terdapat hubungan yang signifikan $\quad(p=0,011) \quad$ antara tingkat kecemasan dengan kadar gula darah sewaktu. Kondisi kronis ini dan kom- plikasi dapat menyebabkan timbulnya kecemasan pada pasien. Menurut pe- nelitian yang dilakukan oleh Sudiyanto (2003) pada hewan coba terjadi pe- ningkatan aktivitas neurotransmiter se- rotonin dan dopamin yang dapat me- ningkatkan kecemasan. Hal ini terjadi pada pasien DM yang dapat disebabkan oleh faktor biologik, yang menyebabkan timbulnya reaksi saraf otonom yang berlebihan dengan me- ningkantnyan sistem saraf simpatis yang melepaskan ketakolamin dan meningkatnya metabolik norepinefrin. Pasien yang mengalami DM terutama DM kronis dapat menimbulkan kece- masan terutama yang telah timbul komplikasi. Pada penelitian ini res- ponden sudah mengalami kompilkiasi dan $40 \%$ diantaranya komplikasi lebih dari satu jenis komplikasi. Cannon da- lam Syarif (1988) menjelaskan bahwa kecemasan dapat menimbulkan gliko- suria pada kucing dan orang normal. Stres emosi dapat menimbulkan gang- guan metabolisme karbohidrat pada orang normal yang nondiabetik. Pada penderita DM proses pengaturan ini mengalami ganguan akibat haemo- statik equelibtrium tidak adekuat. Emosi dapat menambah beratnya kondisi gangguan metabolik pada DM. Pada penderita DM sistem saraf pusat dan pengeluaran epineprin dapat mening- katkan 5 pemecahan glikogen oleh he- par. Hal ini 5 membuktikan bahwa stres emosi dapat menimbulan terjadinya hiperglikemia akibat 30 pengaturan meka- nisme fisologik mengalami keterba- tasan sehingga menyebabkan gangguan pengaturan metabolisme karbo- hidrat sehingga sulit untuk mencapai angka normal. Mekanisme pataofisiologi keter- kaitan antara depresi dengan diabetes masih sedikit yang diketahui, tetapi ada satu kemungkinan adanya kesa- lahan pengaturan fisiologi pada mul- tipel sistem perkembnagan proses peradangan, tidak berfungsinya hipotalamus-pituitary -adrenal (HPA) axis dengan hiperkortison sebagai sin- drome metabolisme (Musselman et al. 2003). Menurut Lane et al (2000) kece- masan dapat meningkatkan kadar gula darah meskipun pada HBA1c lemah kemaknaannya. Stres dapat mening- katkan hormon ACTH yang akan mengaktifkan korteks adrenal untuk mensekresi hormon glukokortikoste- roid 
yang akan meningkatkan gluko- neogenesis sehingga kadar gula darah akan meningkat (Sholeh, 2002). Stres merangsang HPA axis dan menye- babkan perubahan beberapa hormon, peningkatan konsentrasi kortisol serum dan berkurangnya hormon seks dan aktivitas insulin serta peningkatan glukosa darah (Bjorntorp et al 1997). Pada penelitian yang dila-kukan oleh Tarno (2004) tidak ada hubungan antara cemas dan depresi dengan kadar gula darah. Hal ini Karena tingkat cemas yang terjadi pada responden bersifat ringan.

Cemas ringan masih dalam batas fisiolo-gis dan mekanisme fisiologik masih dapat berjalan secara adekuat. Menurut Van Son et al, 2011 me- nyatakan bahwa kondisi emosional penderita DM mengurangi kualitas ke- hidupan, menggangu kontrol glikemia dan meningkatkan resiko timbulnya komplikasi serta meningkatkan angka kematian. Diabetes Melitus berhu- bungan dengan meningkatnya faktor resiko pada beberapa gangguan psi- kiatrik khususnya depresi dan kece- masan (Coolin et al, 2009). Hal ini diperkuat dari hasil penelitian yang dilakukan oleh Lustman et al, 2000 bahwa penderita DM yang mempunyai gangguan psiaktrik akan mening- katkan resiko berkuragnya hasil pengobatan dan manageman pengelo- laan DM dibandingkan pada orang yang tanpa gangguan psikiatrik. Depresi memiliki hubungan yang erat dengan hiperglikemia dan mening- katnya resiko komplikasi DM (de Groot et al, 2001) dan penyakit jantung (Kinder et al, 2002). Penderita DM dengan depresi juga kurang suka terhadap pengobatannya (DiMatteo et $a l$, 2000). Menurut pendapat peneliti penyakit DM dapat menimbulkan kecemasan terutama yang sudah kronis dan timbul komplikasi, disisi lain kecemasan pada penderita DM dapat meingkatkan ka- dar gula (hiperglikemia). Untuk itu edukasi pada penderita DM sangat dibutuhkan guna mengurangi tingkat kecemasan dan mengontrol kadar gula darah.

\section{SIMPULAN}

Berdasarkan hasil penelitian dapat disimpulkan sebagai berikut : 1). Tingkat Kecemasan responden 32,5 \% cemas ringan, 37,5 \% cemas sedang dan $30 \%$ mengalami cemas berat. 2). Kadar gula darah puasa antara $80-109 \mathrm{mg} \%$ sebanyak 12,5 $\%, 110-125 \mathrm{mg} \%$ sebanyak $12,5 \%$ dan lebih dari $126 \mathrm{mg} \%$. sebanyak 75\% 3). Terdapat hubungan yang signifikan $(\mathrm{p}=0,021)$ antara tingkat kecemasan dengan kadar gula darah pada responden. Saran pada penelitian adalah 1). Pada pera- watan pasien DM hendaknya faktor psikologis juga mendapat per-hatian yang sama dengan faktor fisik. 2). Berikan pendidikan kesehatan kepada pasien DM guna mengurangi tingkat kecemasan agar kadar gula darah dapat terkontrol.3). Untuk penelitian berikutnya hendaknya besar sampel lebih banyak. 4). Perlu dilakukan edukasi pada penderita DM guna menurunkan tingkat kecemasan dan mengontrol kadar gula darah.

\section{DAFTAR PUSTAKA}

Almatsier, Sunita. 2010. Penuntun Diet. Cet. 25. Jakarta : Kompas Gramedia

Arikunto, Suharsimi. 1998. Prosedur Penelitian. Jakarta : Rineka Cipta

Azwar, S. 1998. Metode Penelitian. Jakarta : EGC

Brunner and suddarth. 2000. Keperawatan Medikal Bedah. Jakarta : EGC

Fajri, Em dkk. 2000. Kamus Lengkap Bahasa Indonesia. Jakarta : EGC

Masyhuri \& Zainuddin, M. 2008. Metodologi Penelitian Pendekatan Praktis dan Aplikatif. Bandung

Notoatmodjo. 2008. Konsep dan Penerapan Metodologi Penelitian Ilmu Keperawatan Riset. Edisi 2. Jakarta : Salemba Medika

Notoatmodjo, S. 2003. Metodologi Penelitian Kesehatan. Jakarta : PT Rineka Cipta

Nursalam, Siti Pariani. 2001. Pendekatan Praktis Metodologi Riset Keperawatan. Jakarta : Salemba Medika

Nursalam, Soekidjo. 2005. Metodologi Penelitian Kesehatan. Jakarta : Rineka Cipta 
Nursalam. 2003. Metode Riset Keperawatan. Jakarta : Salemba Medika

Pamela. J. Brink, Marylin J. Wood. Langkah Dasar Dalam Perencanaan Riset Keperawatan. Jakarta : EGC

Potter \& Perry. 2006. Buku Ajar Fundamental Keperawatan. Jakarta : EGC

Pranandji, D, K. 2002. Perencanaan Menu Untuk Penderita Diabetes Mellitus. Jakarta : Penebar Swadaya

Setiadi. 2007. Konsep \& Penulisan Riset Keperawatan. Yogyakarta : Graha Ilmu

Soegondo dr sidartawan, dkk. 2000. Penatalaksanaan Diabetes Mellitus Terpadu. Jakarta : FKUI

Soewondo, P. 2002. Pemantauan Pengendalian Diabetes Mellitus; dalam Penatalaksanaan Diabetes Mellitus Terpadu. Jakarta : FKUI

Suyono, dkk. 2001. Buku Ajar Ilmu Penyakit Dalam. Jakarta : Balai Penerbit FKUI

Tjokroprawiro, Askandar. 2000. Diabetes Mellitus Klasifikasi, Diagnosa dan Terapi. Jakarta : Gramedia Pustaka Utama 